\title{
Some Remarks and Experiences on Higher Education and Sustainable Development
}

\author{
Lidia Giuffré1, Silvia E. Ratto ${ }^{2 *}$ \\ ${ }^{1}$ Faculty of Agronomy, Buenos Aires, Argentina \\ ${ }^{2}$ Department of Natural Resources and Environment, University of Buenos Aires, Buenos Aires, Argentina \\ Email: "ratto.silvia@gmail.com
}

Received 14 February 2016; accepted 19 March 2016; published 22 March 2016

Copyright (C) 2016 by authors and Scientific Research Publishing Inc.

This work is licensed under the Creative Commons Attribution International License (CC BY). http://creativecommons.org/licenses/by/4.0/

(c) (i) Open Access

\section{Abstract}

Education for sustainable development should be based on proper environmental management. The general objective of this study is to highlight key aspects of environmental education, with specific objectives. Inclusive education addresses the learning needs with a focus on those who are vulnerable to marginalization and exclusion. Ethics plays a vital role in environmental management and should be a cornerstone to raise awareness of new forms of relationship with the particular and global environment. The cosmovision of indigenous peoples should be respected, including the indissoluble union of each culture with the environment. The feminization of labor is relevant in horticulture crops, with an active role of women in the organization of work. The connections between education and the world of work are key, with preparation for new and indeterminate forms of employment, paying attention to social skills in the context of increasing globalization. University Social Responsibility (USR) implies that the University must act ethically in knowledge transfer, promoting sustainable development. Sustainable development involves new systems of thought, it requires creativity and critical thinking, and an alternative is the creation of role-playing, to lead people to thinking in different ways. It is essential that the new professionals act without static patterns, integrating interdisciplinary teams, to search for the answer to a problem, offering original and innovative alternatives.

\section{Keywords}

Higher Education, Inclusive Education, Role Play, Interdisciplinary Teams, Gender Issues

\section{Introduction}

Incorporating Environmental Sciences in the field of Agrifood Systems has occurred relatively recently. The ${ }^{*}$ Corresponding author. 
rapid changes that are occurring around us are altering the atmosphere and hence our way of life and health, so it is essential to incorporate environmental concepts to all levels of education, to face the challenge of growing within a sustainable project [1]. Agricultural production, and the industry that supports it, need new alternatives that allow them to evolve and maintain competitiveness without affecting the common heritage [2]. When environmental degradation begins to be understood as a social problem, environmental education is a response, with the need for comprehensive training to address specific production areas. Faced with these requirements of society, the Graduate School of the Faculty of Agronomy of Buenos Aires University, through the area of Professional Training, implemented the career to obtain the degree of Specialist in Environmental Management in Agrifood Systems.

In Argentina, there are undergraduate and graduate levels on Agricultural Sciences, Environmental Sciences, Natural Resources, Chemistry, which focus the issue of sustainable development studies, taking into account the principles of proper management of environment.

The World Commission on Environment and Development chaired by Gro Brundtland, generated the report "Our Common Future”, submitted to the United Nations General Assembly in 1987, in which sustainable development is defined as: "Development that meets the needs of the present without compromising the ability of future generations to meet their own needs". This definition, thinking in the period up to 2030, has changed recently to Development that meets the needs of the present while safeguarding Earth's Life-support system, on which the welfare o current and future generations depends [3]. In towns of Costa Rica and Panama a study on the attitude of the people on the maintenance of environmental quality was conducted mainly finding groups environmentally conscious, with utilitarian values, theoretical conservationists, disinterested. In both countries, the most conscious are medium and medium-high socioeconomic groups and those with more education [4].

The initial, most basic model of sustainable development to evolve is referred to as the Triple Bottom Line. The organizational level that once was only one bottom line: finance, now shows that there should be two others: social and environmental [5].

Education for sustainable development should be a primary objective at the university level, must articulate the fundamentals to encourage and enable students to achieve so that they acquire not only knowledge but skills to build this road, a cornerstone of a decent planetary life. It was stated that "Higher education institutions bear a profound, moral responsibility to increase the awareness, knowledge, skills, and values needed to create a just and sustainable future" [6].

The general objective of this study is to highlight key aspects of environmental education for sustainability, with specific remarks to be considered: education for all, environmental ethics, respect to the knowledge of indigenous peoples, gender aspects, university social responsibility, the world of work, role-playing work in the classroom, interdisciplinary group activities.

\section{Remarks and Experiences}

\subsection{Education for All}

Argentina is one of the Latin American countries with most progress in education, according to 2013-14 assessment progress, the country experienced improvements in access to education, a reduction in illiteracy rates and the youngest population growth Sustained education spending over the last decade. Argentina presents progress in access to education, and structural conditions of the quality of their education systems and institutions [7]. Inclusive education seeks to address the learning needs of all children, youth and adults with a specific focus on those who are vulnerable to marginalization and exclusion. Is a cross-cutting theme that runs through early education from to adult, teacher training and curriculum development. Its objective is to enable both teachers and students feel comfortable with diversity and feel that as a challenge and enrichment rather than as a problem [8]. Throughout the world, treaties and laws recognize that education is a fundamental human right. It allows better livelihoods for those who work in agriculture and the urban informal sector, and becomes a catalytic factor for achieving the other development goals [9].

The World Education Forum Korea (05/09/2015) adopted a Declaration on Education 2030 to mobilize all countries, encouraging them to comply with the new agenda, proposing financing and monitoring, and to ensure equal educational opportunities for all. The Director-General of UNESCO, emphasized in his speech: "We know the power of education in eradicating poverty, transforming lives and making progress every Sustainable Development Goals... We must also commit ourselves to give adults the opportunity to continue learning through- 
out life to adapt to rapid change and promote social inclusion; this is not only a human right but a security imperative, inclusive development and peace" [10].

Argentina has a very high proportion of population aged 20 to 64, and a relatively low percentage of children and the elderly, the two "dependent" economic sectors. It is a young country, with decreasing number of children per couple. Experts call this situation the demographic bonus: a unique opportunity to grow and develop, taking advantage of the larger workforce. This "demographic window" began in 1995 and, according to projections, will last until 2040. According to World Bank estimates, the number of seniors will double over the next 35 years, and in that moment, Argentina will face a similar scenario as Europe today: it will be an aging country [11]. If this criterion is applied to university and postgraduate training, with appropriate incentives, younger population should be induced to be educated at these levels.

\subsection{Environmental Ethics}

Agronomic proposal of XXI century produce ethical dilemmas when opposed lines of action are presented, for example in pest control. Scientific progress brings not only benefits or opportunities, but also injury or socioeconomic, cultural, health and ecological risks [12]. Scientific and technological aspects are basic to understand the phenomena and develop solutions for them, while the ethical aspect allows carrying out a proper environmental management, although it lacks the knowledge of all cause-effect generated relationships. In this way, they become relevant values as equity, cooperation, solidarity, responsibility in the use of resources, respect for diversity, among others [13].

Ethics plays a vital role in environmental management and, therefore, must be a cornerstone in any process of environmental education. Collective behavior to generate new ways of relating to their particular and global environment is one of the most important aims of education for the environment [14]. It comes from a rational point of view of moral issues related to the environment. This branch of ethics is increasingly important, given that environmental problems are very present today, because our capacity of dangerous intervention on the environment is increasing.

The problems that face environmental ethics today are basically of three types, international, intergenerational and interspecific. It may be the case on an environmental issue such as climate change, staying involved in various dimensions. It concerns with a subject (person or group of people), natural resources, and is shared by various groups being transmitted from one generation to another. This dimensional structure of the field of environmental problems facilitates ethical discussion and brings clarity to it [15].

\subsection{Regards to Indigenous People Knowledge}

The current environmental crisis is due to an anthropocentric vision that places human as the center of the world, placing us in a condition of superiority, with the rest of nature for our service. This paradigm has led to communities, growing in population, to overcome the resilience of the ecosystems on which we depend for our survival. This has resulted in the depletion of resources, pollution of soil, water, forests and air.

Overcoming the environmental crisis and moving towards sustainable development requires a recreation of our ancestral knowledge, our survival depends on the general welfare of the planet, thus bringing us closer to a biocentric vision, whose origin is housed in the worldview of indigenous peoples [16].

The cosmovision is the way of interpreting the world (Royal Spanish Academy). In the cosmovision of indigenous peoples, indissoluble union with his environment is a common denominator: "every people, every culture is the mirror of the natural world in which they live.” In Argentina live more than 30 Native Peoples organized in more than 900 rural communities, and make up about $10 \%$ of the population (4 million people). No people can develop, if they don't have the base that gives rise: the physical space, the territory which in Quechua is called Pachamama [17].

As an example, forests could not be understood without indigenous communities, whose role in the fight against climate change is undeniable. However, to address this serious problem there must be a comprehensive vision that adds the efforts of the whole society [18]. Forest cover is essential for absorbing and retaining the powerful greenhouse gas carbon dioxide. Protecting and enlarging forested areas would remove more $\mathrm{CO}_{2}$ from the air, an essential part of attempts to stem global warming. The world has never had such strong evidence of the role of indigenous peoples in conserving the forests that represent the one existing solution to climate change. Indigenous people oversee around a fifth of the world's carbon stock, in the form of tropical forests. Altogether, 
168 billion tonnes of carbon are stored on indigenous lands—around three times the world's annual emissionsand this is in danger of being released if the societies looking after these lands are not strengthened. Indigenous communities face problems in getting recognised their role in climate stewardship, as many are poor and lack official rights to their land and access to the legal system [19].

\subsection{Gender Issues}

The higher education sector, being a part of society is also influenced by the existing gender categories and stereotypes of the society. The power division of society between men and women is reflected in academia. Even though the academia perceives itself as progressive part of society, which is the key for innovations, the reality looks different. Today's situation in Higher Education is far away from an equal participation of women and men in the different stages of the higher education career. This is a direct result of the biased situation in society, which is has a lot of benefits reserved for men, but also due to the old structures and the atmosphere within the institutions of higher education. Higher education plays a key role in shaping society and building active citizens. A lot of the people who will take powerful roles in a society have a background in higher education. This implies that a gender equal higher education has also a very huge long term impact on the gender equality within the society. Therefore ESU (European Students Union) fights for a gender equal environment in higher education that preserves equal chances for both women and men [20].

Particularly education that empowers the woman is the key to face malnutrition, which causes over $45 \%$ of child deaths. Educated mothers are more likely to know what practices appropriate home health and hygiene, and more likely to ensure that household resources are allocated so that the nutritional needs of children can be met.

At university level, the action of volunteer students from the Faculty of Agronomy, UBA, as trainers in organizing and monitoring the production of home gardens in peri-urban settlements Escobar (Buenos Aires) stands out. Horticulturists belong to a low socioeconomic status and women play an important role in managing the orchards. The feminization of labor is an important factor, and training by university stakeholders has allowed convert them in protagonists and organizers in the neighborhoods. This can be seen in Feminist Anthropology and Gender, within what is known as the feminization of agriculture, especially in cases of intensive production. Women often take responsibility for family support and accept training and organizational tasks with pride and dedication [21].

\subsection{Higher Education and the World of Work}

Student employment is a part of everyday life in a lot of countries in Europe. Students are often working within the institutions as tutors or student staff. At least here is a responsibility for the institution to give equal chances for women and men. Recruiting procedures should stick to the aim of reaching an equal number of male and female student staff in the institution. This is extremely important in positions, where jobs as student staff give an opportunity for further employment in the institution and an academic career [20]. The fact of having to deal with a job in the real world is a complex moment for recent graduates, who sometimes doubt their real capacity to cope with a changing landscape. Connections between higher education and the world of work are key topics of discussion for innovation in higher education. The signals of the employment system are complex, but many experts and stakeholders agree in the main directions for higher education: greater attention to generic competencies, social skills and personality development, prepare students for the growing globalization, using means beyond classroom teaching [22].

Higher education must be well informed of the expectations of the outside world and respond to the need to prepare students for indeterminate future job tasks, new forms of employment, and to contribute to innovation in society. The skills needed for particular position are constantly evolving so it must prepare graduates to be "trainable at work".

It should strengthen the professional nature of higher education programs, with general skills of students, especially in scenarios in which future training needs may still be unknown [23].

\subsection{University Social Responsibility}

The integration of environmental education and extension programs, training and agricultural education provides 
excellent results. Educating for the future is a premise of the University and environmental education is what enables sustainable development and constitutes a tool for development policies and management.

The principles and values of university life are related to life in society, including the common good and social equity, sustainable development and environment conservation, and specifically on university values: commitment to truth, integrity, excellence and interdisciplinary. The social commitment in professional practice is a new challenge of the knowledge society and is performed based on the principles of the University Social Responsibility (USR). The University as a social actor must act ethically in promoting the transfer of knowledge to society [24].

Three examples of applications with students and professors of the Faculty of Agronomy (University of Buenos Aires) were presented [25].

1) Extension projects with NGO "A Roof for my country”: student act as volunteers working in orchards peri-urban settlements, and advise on analysis ground for a study of fertility and pollution. The objective was to study the content of heavy metals $\mathrm{Cd}, \mathrm{Cr}, \mathrm{Cu}, \mathrm{Ni}, \mathrm{Pb}$ and $\mathrm{Zn}$ in soil of organic orchards. In the first phase soil, studies were conducted in marginal urban settlements in Buenos Aires, in the neighborhoods Santa Brigida and Amancay (Escobar).The second phase was conducted in Los Pinos (Escobar) and Luchetti (Pilar). The average and maximum values for all metals were acceptable for argentine legislation, when compared with the soil quality guideline levels for agricultural use.

2) Inter Institutional relations with the Botanical Garden of Buenos Aires: the intervention of undergraduate and graduate students in sampling and analysis of urban soils. Participation of the youth embedded in a public higher education institution (University of Buenos Aires), promotes the knowledge of themes related with urban soils and the dynamic growth of large cities. Skills that can be applied to other contexts and works of their careers were developed, and attitudes of valuation of belonging settings were observed.

3) Interdisciplinary studies: Environment and use of the land is guided by the Chairs of Soil Science and Sociology. Argentina is a country whose economy depends heavily on agriculture and livestock. In this context, some advanced students of the Faculty of Agriculture are involved in investigating the evaluation of soil quality. The interaction between producers and young professionals generates interaction, mutual understanding and respect for the experience of farmers in land management. Students progress in preparing their graduate work and provide theoretical foundation necessary for the characterization productivity of the soil system.

\subsection{Classroom Work: Role Play}

Sustainable development involves new systems of thought, which requires creativity and critical thinking. That is why plans to implement a methodology entrepreneur "role playing" which allows a search to develop a solution to a practical problem, approaching it from the point of view intellectual and emotional, with a technique of deliberate thought based on the separation of different types of thought and emotions are considered essential to the ability to think. This type of work is related to brain structure: the existence of the neocortex, rational brain, and the limbic system, also called midbrain portion of the brain immediately below the cerebral cortex. In humans, these are the centers of emotion, this is where the different emotions are processed. The methodology [26] is based on separate different aspects of thinking: information, emotion, negative-logical thoughts, optimism, creativity and control. This methodology has been applied in a graduate class in Environmental Management [27].

It is an alternative to the western system of discussion, by creating roles for participants. Hats colors representing different types of thought to the participants, and there is a clear definition of the rules. The organization of work involved the following proposed sequence of hats: white (exposes the facts)-yellow (discussing benefits)-black (critical of the project)-green (creative vision, insights)-red (emotional, impressions, hunches, intuitions)-blue (harvest of ideas and organization). The "Six Thinking Hats" allowed driving thought, expressing different opinions, deviate from the usual roles at any meeting and lead people to think in different ways on a given topic. This might be a desirable approach in the case of a group to study the environmental impact of a project, to discover positive and negative aspects on the environment, and propose a contingency plan.

\subsection{Working in Interdisciplinary Teams}

It is necessary for new professionals to adopt independent positions, no static patterns, their integration in inter- 
disciplinary teams, to search for the answer to a problem that is usually not unique, offering original and innovative alternatives. This work is very useful in graduate programs in those involved are graduates of various disciplines, such as in the Specialization in Environmental Management in Agrifood Systems, where different professional interact: agronomists, lawyers, economists, environmental scientists, graduates in landscape science, biochemists, graduates in food science. Real scenarios are proposed and carried out in groups: environmental impact assessments in high-impact productions, as feedlots or agribusiness as chicken slaughterhouse. Also assessments of carcinogenic risk of inhaling heavy metals are discussed.

\section{Conclusions}

Inclusive education addresses the learning needs with a focus on those who are vulnerable to marginalization and exclusion.

Ethics plays a vital role in environmental management and should be a cornerstone to raise awareness of new forms of relationship with the particular and global environment.

The cosmovision of indigenous people should be respected, including the indissoluble union of each culture with the environment.

The feminization of labor is an important aspect especially in intensive crops, and women have an active role in the organization of community work.

The connections between higher education and the world of work are key issues for future tasks of indeterminate employment and new forms of work, paying attention to social skills in the context of increasing globalization.

There should be social commitment in professional practice, the University Social Responsibility (USR), implies that the university as a social actor, acts in knowledge transfer promoting sustainability.

Sustainable development involves new and different thinking systems, requires creativity and critical thinking, and an alternative to the system is the creation of role-playing, to deviate from the usual roles and lead people to think in different ways.

It is also essential that the new professionals take independent positions, without static patterns, integrating interdisciplinary teams, to search for the answer to a problem that is usually not unique, offering original and innovative alternatives.

\section{References}

[1] Wais de Bagden, I. (2004) En “Ambiente y Salud, el Ambiente en el Siglo XXI”. In: Bertello, L., Ed., Comisión de Medio Ambiente, Diócesis de San Isidro, Buenos Aires, 21-43.

[2] Morello, J. and Solbrig, O. (1997) Argentina Granero del Mundo: Hasta cuándo? La degradación del sistema agroproductivo de la Pampa Húmeda y sugerencias para su recuperación. 280 pags. Orientación Gráfica Editora, Buenos Aires.

[3] Griggs, D., Stafford-Smith, M., Gaffney, O., Rockström, J., Öhman, M., Shyamsundar, P., Steffen, W., Glaser, G., Kanie, N. and Noble, I. (2013) Nature Sustainable, Development Goals for People and Planet. Nature, 495, 305-307. http://dx.doi.org/10.1038/495305a

[4] Lentini Gilli, V. (2004) Valores ambientales de los ciudadanos: Comparación de resultados entre Costa Rica y Panamá. UNIMER.

http://www.unimercentroamerica.com/biblioteca_virtual/ComparacionValores_ambientalesCR_y_Panama.pdf

[5] Johnston, A. (2007) Higher Education for Sustainable Development. Final Report of International Action Research Project. http://www.oecd.org/education/innovationeducation/centreforeffectivelearningenvironmentscele/45575516.pdf

[6] Cortese, A. (2003) http://www.aashe.org/resources/pdf/Cortese_PHE.pdf

[7] Olaberría, G. (2014) La Argentina es uno de los paises más igualitarios de la región en materia de escolaridad. Página 12, 30 de enero de 2014.

[8] UNESCO, Bangkok (2015) Inclusive Education. http://www.unescobkk.org/education/inclusive-education/what-is-inclusive-education/

[9] UNESCO (2014) Enseñanza y aprendizaje: Lograr la calidad para todos. Informe de Seguimiento de la EPT (Enseñanza para Todos) en el Mundo. http://unesdoc.unesco.org/images/0022/002261/226159s.pdf

[10] Bokova, I. (2015) Disertación en el Foro Mundial de Educación. http://es.unesco.org/world-education-forum-2015/about-forum/programa

[11] Dillon, A. (2014) El país envejece y afirman que se invierte poco en los jóvenes. Clarín. www.clarin.com 
[12] Freyre, E. (1999) Elementos éticos para la agricultura de hoy. Agricultura Orgánica Año, 5.

[13] Jobe, M.J. (2003) Incorporación de la Educación Ambiental en el curriculo escolar. www.estrucplan.com.ar/Artículos/curiculum.asp

[14] Ruiz Cabezas, M.R. (2008) Fomento de la ética ambiental. Gestiopolis. http://www.gestiopolis.com/fomento-etica-ambiental/

[15] Marcos, A. (2001) Principio de precaución: Un enfoque (neo)aristotélico. www.fyl.uva.es/ wfilosof/webMarcos/.../A_Marcos_ETAM_ELCHE.doc

[16] Pérez Pino, V. (2010) Educación ambiental y cosmovisión de los pueblos originarios. Comisión Nacional del Medio Ambiente. http://www.ceh.cl/GEFSDH2010/GEFpdf/Seminarios/fo-article-29181.pdf

[17] Ñancucheo, R. (2015) Los Pueblos Originarios y la relación con el ambiente. Secretaría de Ambiente y Desarrollo Sustentable. http://www.ambiente.gov.ar/default.asp?IdArticulo=9509

[18] Global Landscape Forum. Lima 2014, La Madre Tierra está sufriendo y todos somos responsables. Es el momento de actuar. http://www.cop20.pe/16979/la-madre-tierra-esta-sufriendo-y-todos-somos-responsables-es-el-momento-de-actuar/

[19] Global Landscapes Forum (2015) Indigenous People Keep Carbon Locked in Forests. SciDevNet. http://www.landscapes.org/scidevnet-glf-2015-indigenous-people-keep-carbon-locked-forests/

[20] ESU. European Students Union (2011) Policy Paper: Gender Equality in Higher Education. www.esu-online.org

[21] Giuffré, L., Ciarlo, E., Marbán, L., Rios, R.P., Vespasiano, C., Sammartino, F. and Arata, L. (2015) Family Horticulture as Precursory Activity for Social Development: Social Structure and Soil Analysis for a Sustainable Production. International Journal of Business \& Social Science, 6, 29-36.

[22] Teichler, U. (1999) Higher Education Policy 12: 285-312. Higher Education Policy and the World of Work: Changing Conditions and Challenges. http://dx.doi.org/10.1016/S0952-8733(99)00019-7

[23] IIEP. International Institute for Education Plannig (2015) UNESCO. United Nations Educational, Scientific and Cultural Organization.

[24] Domínguez Pachón, M.J. (2009) Responsabilidad Social Universitaria. Humanismo y Trabajo Social, 8, 37-67.

[25] Giuffré, L. and Ratto, S. (2014) A New Paradigm in Higher Education: University Social Responsibility (USR). Journal of Education \& Human Development, 3, 231-238.

[26] De Bono, E. (1985) Six Thinking Hats: An Essential Approach to Business Management. Little, Brown, \& Company (Ed).

[27] Giuffré, L., Cucher, S., Bonafina, C. and Ratto, S. (2010) Educación para el desarrollo sostenible mediante la técnica de pensamiento lateral deliberado. Rev. Fac. Agr, 30, 81-84. 